\title{
Fabrication and Characterization of In Situ Synthesized SiC/Al Composites by Combustion Synthesis and Hot Press Consolidation Method
}

\author{
Hongyu Yang, ${ }^{1}$ Erting Dong, ${ }^{2}$ Bingqi Zhang, ${ }^{3}$ Yanyan Yuan, ${ }^{1}$ and Shili Shu ${ }^{4}$ \\ ${ }^{1}$ National Demonstration Center for Experimental Materials Science and Engineering Education, \\ Jiangsu University of Science and Technology, Zhenjiang 212003, China \\ ${ }^{2}$ Department of Materials Engineering, Henan Institute of Technology, Xinxiang 453000, China \\ ${ }^{3}$ Datang Northeast Electric Power Test And Research Institute, No. 3195 Weishan Street, Changchun 130000, China \\ ${ }^{4}$ State Key Laboratory of Luminescence and Applications, Changchun Institute of Optics, Fine Mechanics and Physics, \\ Chinese Academy of Sciences, Changchun 130033, China
}

Correspondence should be addressed to Shili Shu; shushili@ciomp.ac.cn

Received 27 September 2017; Revised 8 November 2017; Accepted 20 November 2017; Published 11 December 2017

Academic Editor: Guosong Wu

Copyright (C) 2017 Hongyu Yang et al. This is an open access article distributed under the Creative Commons Attribution License, which permits unrestricted use, distribution, and reproduction in any medium, provided the original work is properly cited.

\begin{abstract}
The in situ SiC/Al composites were fabricated in Al-Si-C systems with different $\mathrm{Si} / \mathrm{C}$ mass ratios and holding time by the method of combustion synthesis and hot press consolidation. The influences of $\mathrm{Si} / \mathrm{C}$ mass ratio and holding time on the phase constitution, microstructure, and hardness of the composites were investigated. The results indicate that the increase of $\mathrm{Si} / \mathrm{C}$ mass ratio leads to more uniform size distribution of the $\mathrm{SiC}$ particles in the $\mathrm{Al}$ matrix. Moreover, by improving the Si/C mass ratio from $4: 1$ to $5: 1$, the maximum size of $\mathrm{SiC}$ particle was reduced from $4.1 \mu \mathrm{m}$ to $2.0 \mu \mathrm{m}$. Meanwhile, the percentage of submicroparticles was increased from $22 \%$ to $63 \%$, and the average hardness value of the composites was increased by $13 \%$. In addition, when the holding time is set to be fifteen minutes, the $\mathrm{Al}_{4} \mathrm{C}_{3}$ phase did not exist in the composites because of its total reactions with $\mathrm{Si}$ atoms to form $\mathrm{SiC}$ particles, and the average hardness value was $73.8 \mathrm{HB}$.
\end{abstract}

\section{Introduction}

The $\mathrm{SiC}$ reinforced aluminum matrix $(\mathrm{SiC} / \mathrm{Al})$ composites have become very promising materials in the fields of semiconductor packaging, automobile, and aeronautics industry due to their high thermal conductivity and low coefficient of thermal expansion, lightweight, high strength, and wearresistance [1-5]. For example, the $\mathrm{SiC} / \mathrm{Al}$ composites which we fabricated in this work can be used for engine piston and heat sink $[6,7]$. Therefore, the $\mathrm{SiC} / \mathrm{Al}$ composites are actively investigated in an effort to improve their comprehensive properties $[8,9]$.

In recent years, several methods have been applied to fabricate the $\mathrm{SiC} / \mathrm{Al}$ composites, such as stir casting [10$12]$, hot pressing sintering $[2,13]$, powder metallurgy [8], liquid pressing process [14], high pressure solidification [15], and squeeze-cast [16]. Nevertheless, in these methods the reinforcing $\mathrm{SiC}$ particles are usually directly added to $\mathrm{Al}$ matrix to form ex situ $\mathrm{SiC} / \mathrm{Al}$ composites. The ex situ $\mathrm{SiC} / \mathrm{Al}$ composites have several inherent disadvantages [17-19]: (I) the reinforcing $\mathrm{SiC}$ particles is difficult to be uniformly dispersed into the $\mathrm{Al}$ matrix; (II) during the incorporation of particles, interfaces between $\mathrm{SiC}$ and $\mathrm{Al}$ matrix are easy to be contaminated. In addition, cracks could appear in the interfaces due to the formation of thin oxide layers on the surfaces of the particles. To overcome these drawbacks stated above, the research on $\mathrm{Al}$ matrix composites is moving in two directions: one is metallic glasses replaced by typical ceramic particles reinforcements [20-22]; the other is in situ methods replaced by traditional ex situ methods.

Compared to the ex situ methods, in the in situ methods the reinforcement is synthesized through a chemical reaction among the pristine elemental materials themselves in the matrix $[23,24]$. Therefore, the interfaces between 
TABLE 1: Characteristics of the raw materials used in experiment.

\begin{tabular}{lcccc}
\hline Raw materials & Purity (wt.\%) & Particle size & Morphology & Production units \\
\hline $\mathrm{Al}$ & $\geq 99.7$ & $<48 \mu \mathrm{m}$ mesh & Spherical particles & \\
$\mathrm{Si}$ & $\geq 99.9$ & $<48 \mu \mathrm{m}$ mesh & Irregularly shaped particles & Shanghai ST-Nano Science and Technology Co., Ltd. \\
C-black & $\geq 99.9$ & $100 \pm 20 \mathrm{~nm}$ & Spherical particles & \\
\hline
\end{tabular}

reinforcement and matrix are very clean, and the bonding strength is strong. At the same time, the reinforcing particles formed by the in situ method are finer in size and uniformly distributed into the matrix [25, 26]. Nie et al. [27] fabricated the in situ $\mathrm{SiC} / \mathrm{Al}$ composites by the structural evolution of $\mathrm{TiC}$ in Al-Si melt. They reported that the synthesis of the $\mathrm{SiC}$ particles occurred via the gradual reaction between the $\mathrm{TiC}$ and the $\mathrm{Si}$ atoms, and the needle-like $\mathrm{TiAl}_{x} \mathrm{Si}_{y}$ phase simultaneously is formed. The needle-like $\mathrm{TiAl}_{x} \mathrm{Si}_{y}$ phase plays a detrimental role in the mechanical properties of the composites. Du et al. fabricated the in situ $\mathrm{SiC} / \mathrm{Al}$ composites by liquid-solid reaction [28] and master alloy casting method $[6,29]$, respectively. They reported that the formation of $\mathrm{SiC}$ particles was attributed to the reaction between dissolved $\mathrm{Si}$ atoms and $\mathrm{Al}_{4} \mathrm{C}_{3}$ intermediate phase, which indicates that the fabrication of in situ $\mathrm{SiC} / \mathrm{Al}$ composites through gradual phase transformation mechanism was feasible. However, the formation process of the in situ $\mathrm{SiC}$ particles is reversible if the intermediate phase $\mathrm{Al}_{4} \mathrm{C}_{3}$ is as carbon source. Therefore, different reaction conditions will significantly impact on the synthesis reaction. Meanwhile, the effects of $\mathrm{Si} / \mathrm{C}$ ratio and holding time on the fabrication of the in situ $\mathrm{SiC} / \mathrm{Al}$ composites have not been involved in previous work. Besides, to our knowledge, the method of the combustion synthesis and hot press consolidation is another effective way for the fabrication of in situ composites [30-32]. This method takes advantage of low energy requirement, one step forming process, density, and high purity of the products.

Thus, the objectives of the present work are to fabricate the in situ $\mathrm{SiC} / \mathrm{Al}$ composites in an Al-C-Si system using the method of the combustion synthesis and hot press consolidation. Meanwhile, the effects of $\mathrm{Si} / \mathrm{C}$ mass ratio and holding time on the phase constitution, microstructure, and hardness of the in situ $\mathrm{SiC} / \mathrm{Al}$ composites were investigated.

\section{Experiment}

In this work, commercial $\mathrm{Al}$ powders, $\mathrm{Si}$ powders, and $\mathrm{C}$ black powders were used for making the powder blends. The detailed information of the raw materials is given in Table 1. The SEM images and particle size distribution are shown in Figure 1.

The detailed fabrication process procedure is shown as follows: First, $\mathrm{Al}$ powders and carbon powders were mixed with different $\mathrm{Si} / \mathrm{C}$ mass ratio (as shown in Table 2 ). The dispersion method was a dry process using ball milling. The mixtures of powders were sealed into a $500 \mathrm{~mL}$ volume zirconia jar together with $\mathrm{ZrO}_{2}$ milling balls (ball to powder mass ratio of 10$)$. The jar was aerated with argon gas to protect the powder from excessive oxidation. The milling was
TABLE 2: Weight of the raw materials with different Si/C mass ratio used in the fabrication procedure.

\begin{tabular}{lccc}
\hline Si/C mass ratio & $\mathrm{Al}$ & $\mathrm{Si}$ & $\mathrm{C}$ \\
\hline $4: 1$ & $75 \mathrm{~g}$ & $20 \mathrm{~g}$ & $5 \mathrm{~g}$ \\
$5: 1$ & $70 \mathrm{~g}$ & $25 \mathrm{~g}$ & $5 \mathrm{~g}$ \\
$6: 1$ & $65 \mathrm{~g}$ & $30 \mathrm{~g}$ & $5 \mathrm{~g}$ \\
\hline
\end{tabular}

carried out on a roller ball milling machine at $35 \mathrm{rpm}$ for $8 \mathrm{~h}$. Second, the mixtures were cold pressed into cylindrical compacts with the diameter of $28 \mathrm{~mm}$ and height of $30 \mathrm{~mm}$. Third, the powder compact was contained in a graphite mold. And the graphite mold with powder compact was put in a self-made vacuum thermal explosion furnace as illustrated in Figure 2, in which the combustion synthesis and hot press consolidation experiment was conducted. During this process, the temperature was monitored by W5-Re26 thermocouples and the heating rate was $20^{\circ} \mathrm{C} / \mathrm{min}$. The furnace temperature was set to $950^{\circ} \mathrm{C}$, and after different holding time, the pressure of $30 \mathrm{MPa}$ was applied. Finally, the compact was cooled inside the furnace to room temperature. Notice that the compact was heated and cooled in a vacuum environment $\left(\leq 5 \times 10^{-2} \mathrm{~Pa}\right)$.

The phase constitution of the samples was investigated by X-ray diffraction (XRD, Model D/Max 2500PC, Rigaku, Tokyo, Japan) with $\mathrm{Cu} \mathrm{K}_{\alpha}(\lambda=0.154 \mathrm{~nm})$ radiation. The samples were firstly mechanical ground, then polished down to a diamond finish of $1.5 \mu \mathrm{m}$, and then etched in a hybrid solution of $5 \% \mathrm{HCl}$ and $95 \%$ ethanol at room temperature for $5 \mathrm{~s}$ for the microstructural observations. The morphology was observed by scanning electron microscopy (SEM, Model Evol8 Carl Zeiss, Oberkochen, Germany). The size measurement and distribution statistics of $\mathrm{SiC}$ particle were performed with the Nano Measurer software. The hardness tests were conducted on a XHB-3000 digital Brinell hardness tester according to the ASTM E10-14 standard.

\section{Results and Discussion}

3.1. Fabrication of In Situ SiC/Al Composites. The in situ $\mathrm{SiC} / \mathrm{Al}$ composite was firstly fabricated in an Al-Si-C system with the $\mathrm{Si} / \mathrm{C}$ mass ratio of $5: 1$ at $950^{\circ} \mathrm{C}$ and holding time for $15 \mathrm{~min}$. Figure 3 shows the XRD pattern of the fabricated $\mathrm{SiC} / \mathrm{Al}$ composite. It can be seen that the in situ $\mathrm{SiC} / \mathrm{Al}$ composite was successfully fabricated and no $\mathrm{Al}_{4} \mathrm{C}_{3}$ phase existed in the composite. Figure 4(a) shows the SEM images of the etched surfaces of the fabricated SiC/Al composite. It can be observed that a large quantity of irregular blockyshaped particles is distributed in the Al matrix. By the EDS 


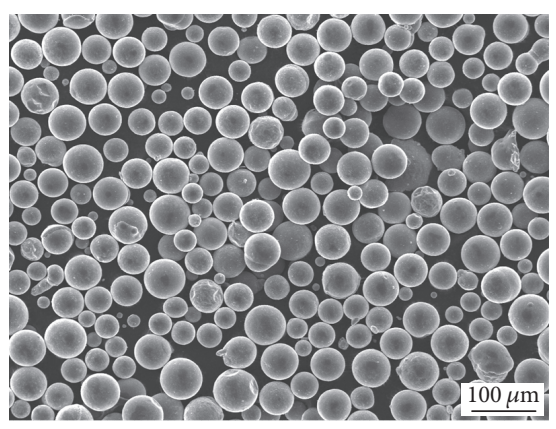

(a)

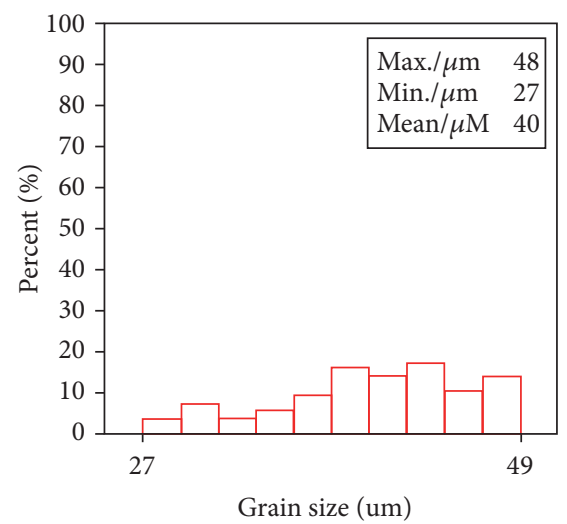

(d)

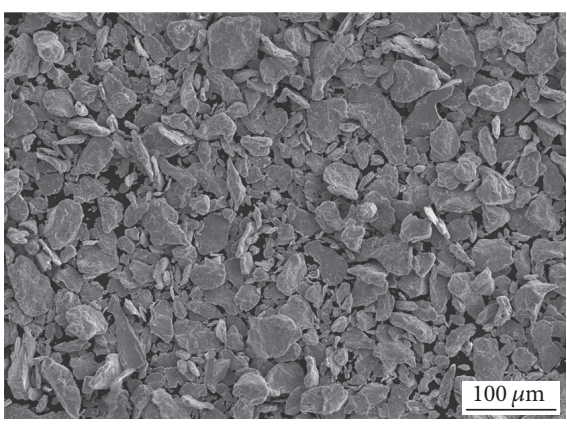

(b)

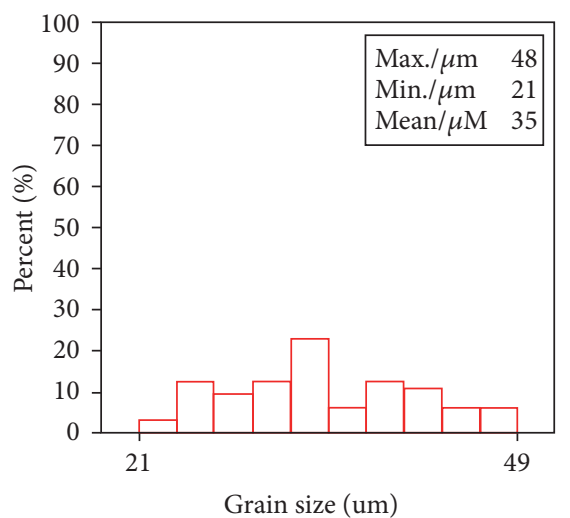

(e)

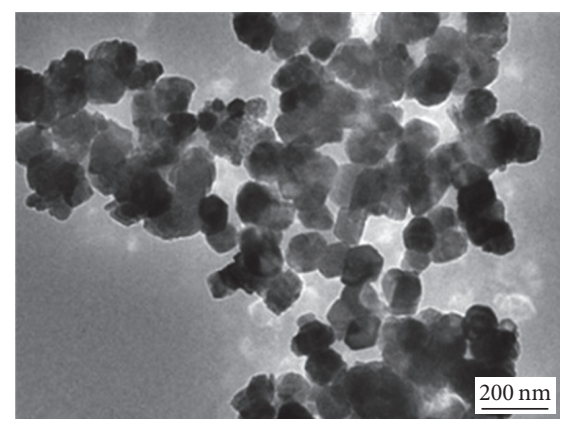

(c)

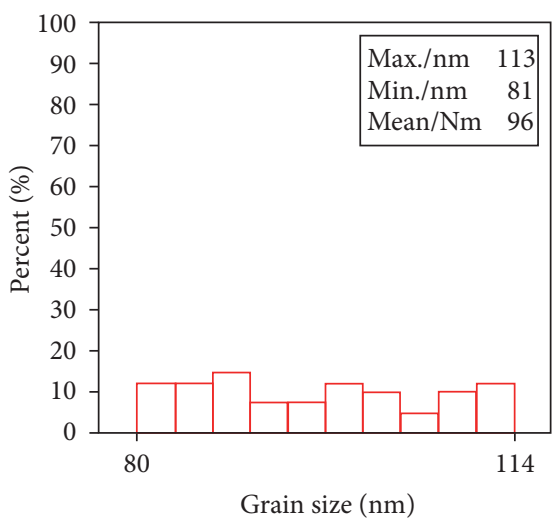

(f)

FIgure 1: The SEM images of (a) Al, (b) Si, and (c) C (provided by Shanghai ST-Nano Science and Technology Co., Ltd.); particle size distribution of (d) $\mathrm{Al},(\mathrm{e}) \mathrm{Si}$, and (f) C.

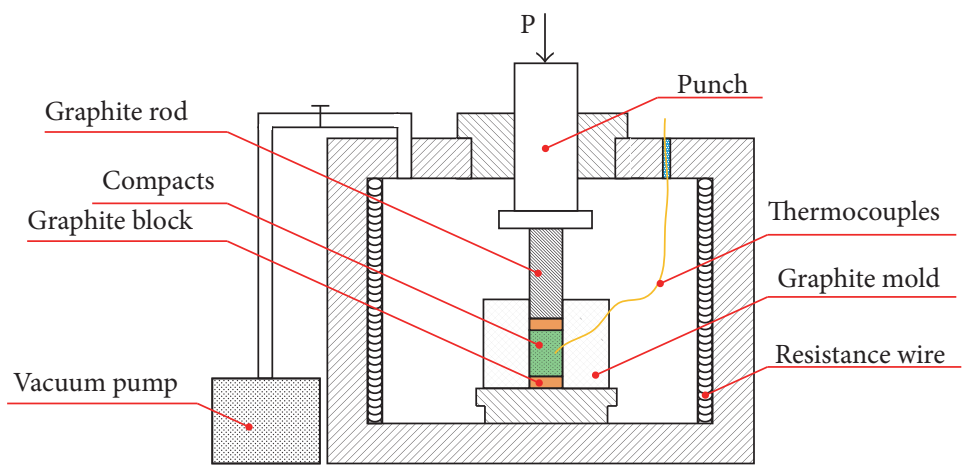

FIGURE 2: Schematic of the equipment for the combustion synthesis and hot press consolidation experiment.

analysis of the content of Si and C elements in (Figure 4(b)), the irregular blocky-shaped particles are identified as SiC. According to $\mathrm{Du}$ et al. reports [28], it can be known that the formation of $\mathrm{SiC}$ is achieved via the replacement reaction of $\mathrm{Si}$ and $\mathrm{Al}_{4} \mathrm{C}_{3}$. Hence the obtained $\mathrm{SiC}$ particles are liable to inherit morphological characteristics of the reactant of $\mathrm{Al}_{4} \mathrm{C}_{3}$. Figures 4(c)-4(f) show the element mapping of the SiC/Al composite. It can be seen that there are bulk crystal Si and $\mathrm{SiC}$ particles, and they are nearly uniformly distributed in the $\mathrm{Al}$ matrix. Meanwhile, a little amount of oxygen can be found, because the raw materials contained trace amounts of oxygen. Finally, the above results indicate that the pure $\mathrm{SiC} / \mathrm{Al}$ composites are synthesized by in situ method at $950^{\circ} \mathrm{C}$ and holding time for $15 \mathrm{~min}$ by combustion synthesis and hot press consolidation.

3.2. Effect of the Si/C Mass Ratio. In order to investigate the effect of $\mathrm{Si} / \mathrm{C}$ mass ratio on the phase constitution and 


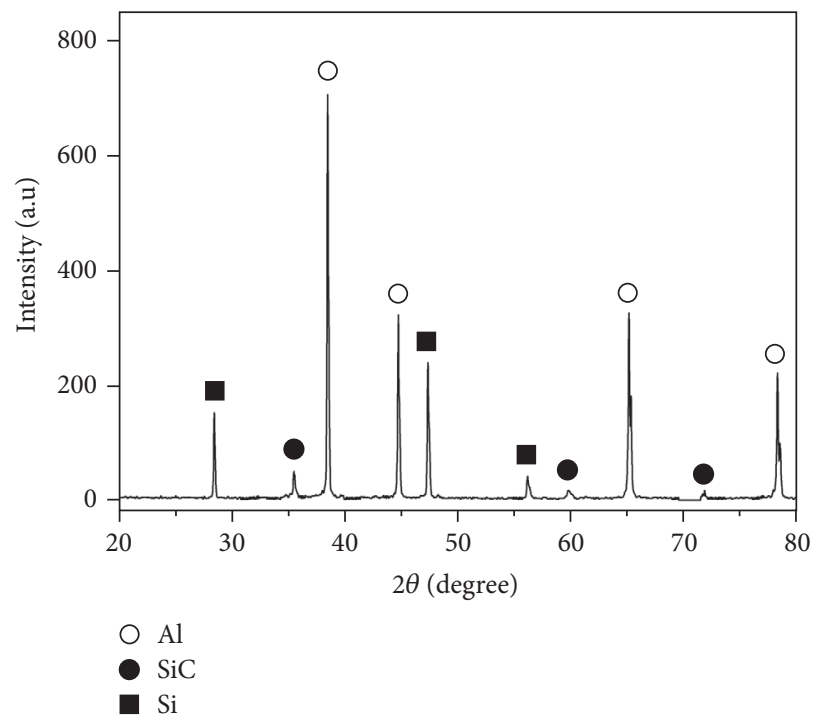

FIGURE 3: XRD pattern of the $\mathrm{SiC} / \mathrm{Al}$ composites with $\mathrm{Si} / \mathrm{C}$ mass ratio of $5: 1$.

microstructure of the in situ $\mathrm{SiC} / \mathrm{Al}$ composites, the $\mathrm{SiC} / \mathrm{Al}$ composites with different the $\mathrm{Si} / \mathrm{C}$ mass ratio were fabricated.

Figure 5 shows the XRD patterns of the $\mathrm{SiC} / \mathrm{Al}$ composites with different $\mathrm{Si} / \mathrm{C}$ mass ratio $(4: 1,5: 1$, and $6: 1)$. It can be seen that the main phases are $\mathrm{Al}, \mathrm{Si}$, and $\mathrm{SiC}$ in these samples. The peak intensity of the $\mathrm{SiC}$ phase is enhanced with increasing of the $\mathrm{Si} / \mathrm{C}$ mass ratio. Figure 6 shows the SEM images of etched surfaces of the $\mathrm{SiC} / \mathrm{Al}$ composites with different $\mathrm{Si} / \mathrm{C}$ mass ratios. It clearly reveals that the irregular blocky-shaped $\mathrm{SiC}$ particles are formed in these samples. Nevertheless, the amount of $\mathrm{SiC}$ particles increases and the size decreases with the increase of $\mathrm{Si} / \mathrm{C}$ mass ratio.

Figure 7 shows the corresponding size distribution of the in situ synthesized $\mathrm{SiC}$ particles in the tested samples. As shown in Figure 7(a), the maximum and average value of the $\mathrm{SiC}$ particles size in the composites with the $\mathrm{Si} / \mathrm{C}$ mass ratio of $4: 1$ are about $4.1 \mu \mathrm{m}$ and $1.6 \mu \mathrm{m}$, respectively, and the percentage of the submicroparticle is about $22 \%$ in total. As shown in Figure $7(\mathrm{~b})$, when the $\mathrm{Si} / \mathrm{C}$ mass ratio is $5: 1$, the maximum and average value of the $\mathrm{SiC}$ particles size are reduced to be $2.0 \mu \mathrm{m}$ and $1 \mu \mathrm{m}$, respectively. Meanwhile, the percentage of submicroparticles increases to about $63 \%$. As shown in Figure 7(c), when the Si/C mass ratio is $6: 1$, the maximum and average value of the $\mathrm{SiC}$ particle size are reduced to be $1.9 \mu \mathrm{m}$ and $0.9 \mu \mathrm{m}$, respectively. The percentage of submicroparticles increases up to about $66 \%$. The results indicate that the increase of the $\mathrm{Si} / \mathrm{C}$ mass ratio can reduce the size of the $\mathrm{SiC}$ particles and lead to more uniform distribution of the particle size. Particularly, when the Si/C mass ratio increases from $4: 1$ to $5: 1$, the size of $\mathrm{SiC}$ particles is reduced significantly. The reason is that when the concentration of $\mathrm{Si}$ in the system increases, the contact opportunity between $\mathrm{Al}_{4} \mathrm{C}_{3}$ phase and $\mathrm{Si}$ atoms increases; consequently $\mathrm{SiC}$ nucleation rate increases. The average hardness value of the $\mathrm{SiC} / \mathrm{Al}$ composites with different $\mathrm{Si} / \mathrm{C}$ mass ratio $(4: 1,5: 1,6: 1)$ is
$65.3 \mathrm{HB}, 73.8 \mathrm{HB}$, and $75.6 \mathrm{HB}$, respectively. It can be found that when the percentage of the $\mathrm{SiC}$ submicroparticle in the composites increases from $22 \%$ to $63 \%$, the hardness is increased by $13 \%$.

The above results indicate that the increase of the Si/C mass ratio is helpful to synthesis of $\mathrm{SiC}$ particles. However, when the remaining $\mathrm{Si}$ in $\mathrm{Al}$ matrix is much more than the eutectic composition (12.6\%) after in situ synthesized $\mathrm{SiC}$, the additional Si leads to the rapid reduction of the compactness, strength, and ductility of the sample [33]. As a result, $\mathrm{Si}$ content is about $12 \%$ in research on most Al-Si alloy [3436]. Therefore, the $\mathrm{Si} / \mathrm{C}$ mass ratio of $5: 1$ is considered to be reasonable for the fabrication of the in situ $\mathrm{SiC} / \mathrm{Al}$ composites.

3.3. Effect of the Holding Time. The holding time in the fabrication process of the in situ $\mathrm{SiC} / \mathrm{Al}$ composites is the dynamic factor of direct impact on the reaction process; therefore the $\mathrm{SiC} / \mathrm{Al}$ composites with the $\mathrm{Si} / \mathrm{C}$ mass ratio of $5: 1$ under different holding time $(0,15,30 \mathrm{~min})$ were fabricated, respectively. Figure 8 shows the XRD patterns of the $\mathrm{SiC} / \mathrm{Al}$ composites with different holding time $(0,15$, and $30 \mathrm{~min})$. It can be seen that the products in the sample with the holding time of $15 \mathrm{~min}$ are mainly $\mathrm{Al}, \mathrm{Si}$, and $\mathrm{SiC}$ phases, shown in Figure 8(b). Meanwhile, the $\mathrm{Al}_{4} \mathrm{C}_{3}$ phases appear in the sample without holding and with the holding time of 30 min as shown in Figure 8((a) and (c)).

In the $\mathrm{Al}-\mathrm{Si}-\mathrm{C}$ systems, the synthesis reaction of $\mathrm{SiC}$ is mainly limited by the diffusion of $\mathrm{Si}$ atoms. If without holding in the fabrication, the first generated $\mathrm{Al}_{4} \mathrm{C}_{3}$ phases have not enough time to react completely with $\mathrm{Si}$ atoms. Meanwhile, when the holding time is extended to $30 \mathrm{~min}$, the $\mathrm{Si}$ concentration in the system is decreased with the continual reaction between $\mathrm{Al}_{4} \mathrm{C}_{3}$ and $\mathrm{Si}$ atoms. The above two factors will lead the remaining of $\mathrm{Al}_{4} \mathrm{C}_{3}$ phases to appear in composites. 


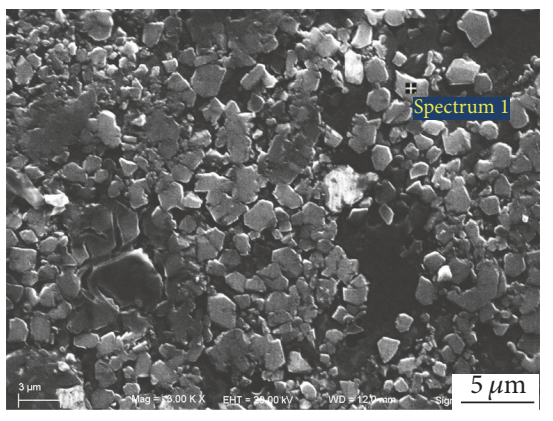

(a)

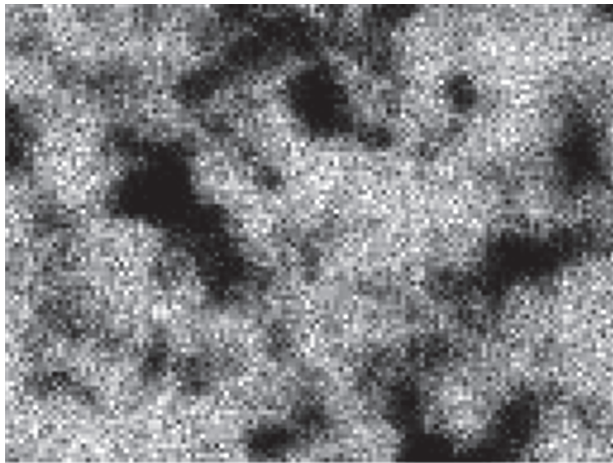

$20 \mu \mathrm{m}$

(c)

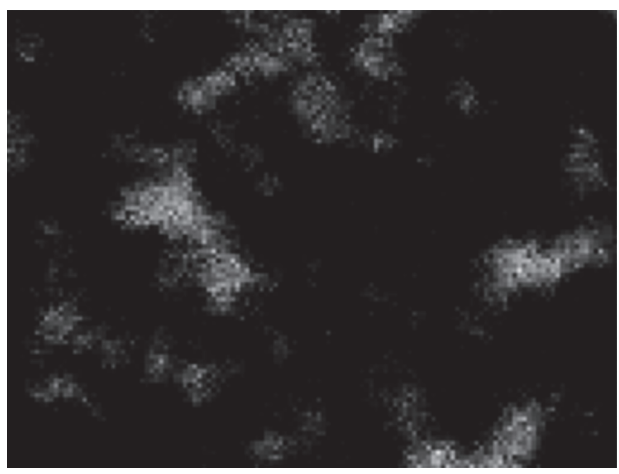

$20 \mu \mathrm{m}$

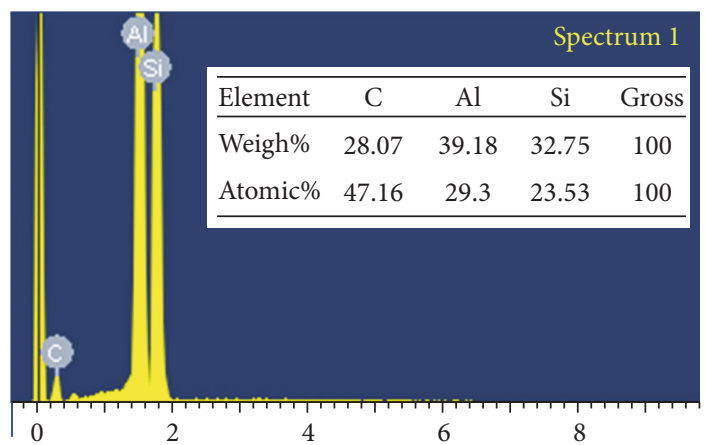

(b)

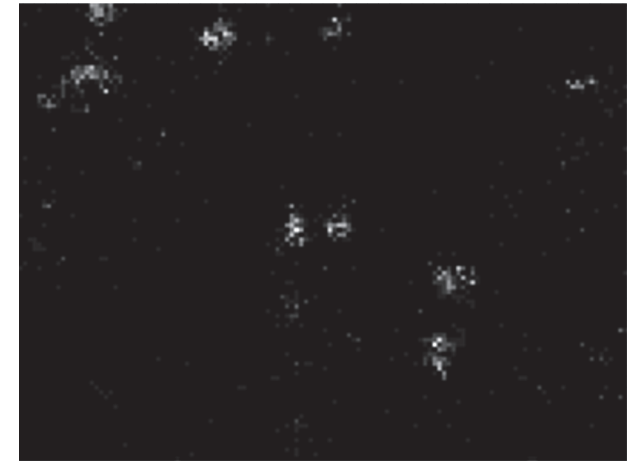

$20 \mu \mathrm{m}$

(d)

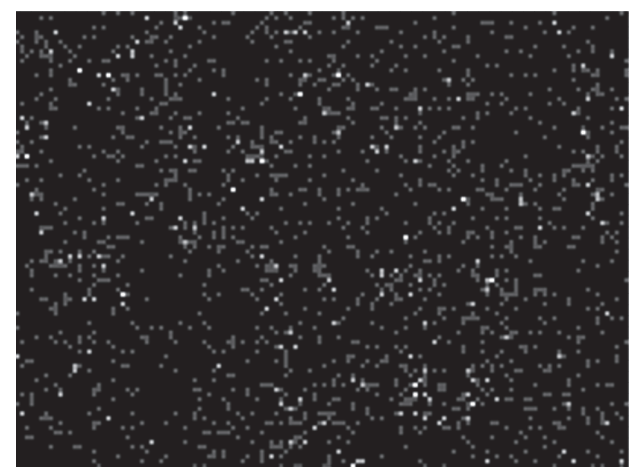

$20 \mu \mathrm{m}$

(e)

(f)

Figure 4: (a) SEM images of the etched surfaces of the SiC/Al composites with Si/C mass ratio of $5: 1$, (b) EDS analysis of the SiC particle as indicated in (a), and element mappings of (c) Al, (d) O, (e) Si, and (f) C.

Figure 9 shows the SEM images of etched surfaces of the $\mathrm{SiC} / \mathrm{Al}$ composites with different holding time $(0,15$, and $30 \mathrm{~min})$. It can be seen that the in situ $\mathrm{SiC}$ particles with the irregular blocky-shape formed in the three samples. Nevertheless, SiC particles are few when the holding time is $0 \mathrm{~min}$. With the holding time of $15 \mathrm{~min}$, the amount of $\mathrm{SiC}$ particles is increased. Meanwhile, with further increase of the holding time $(30 \mathrm{~min})$, the amount of the $\mathrm{SiC}$ particles has no obvious changes. Figure 10 shows the corresponding size distribution of the in situ synthesized $\mathrm{SiC}$ particles in the tested samples under different holding times. It can be seen that holding times had no discernible effect on the SiC particles size. Nevertheless, the average hardness value of the $\mathrm{SiC} / \mathrm{Al}$ composites with different holding time $(0 \mathrm{~min}, 15 \mathrm{~min}$, and $30 \mathrm{~min}$ ) is measured to be $58.5 \mathrm{HB}, 73.8 \mathrm{HB}$, and $71.6 \mathrm{HB}$, respectively. It can be found that when holding time is $15 \mathrm{~min}$ the composites have the largest hardness value. Particularly, if there is no holding time during fabrication process, the hardness value of the $\mathrm{SiC} / \mathrm{Al}$ composites is decreased by $21 \%$ because the $\mathrm{SiC}$ particles are few in this sample. 


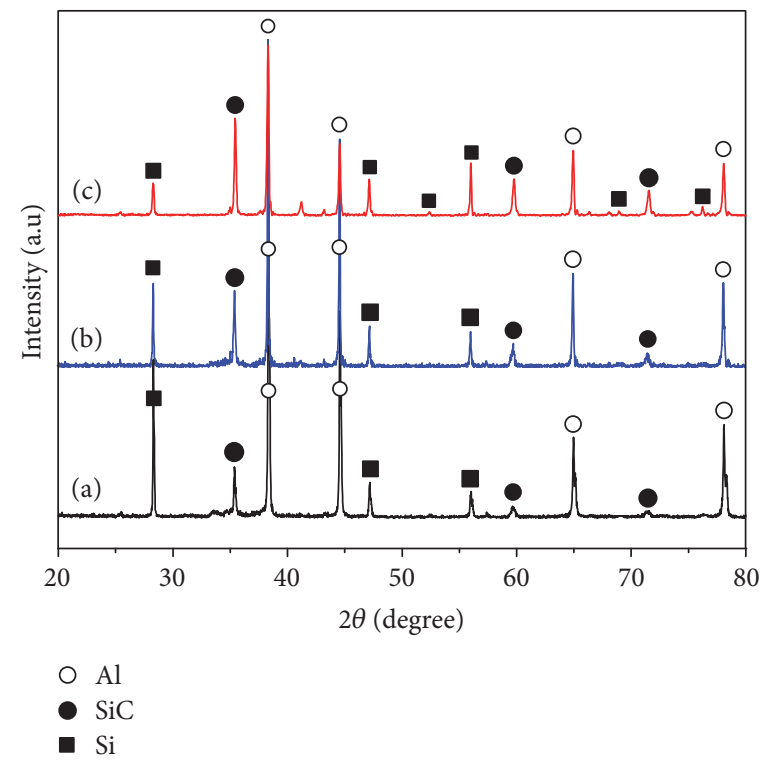

FIGURE 5: XRD patterns of the $\mathrm{SiC} / \mathrm{Al}$ composites with different $\mathrm{Si} / \mathrm{C}$ mass ratio: (a) Si/C mass ratio $=4: 1$, (b) $\mathrm{Si} / \mathrm{C}$ mass ratio $=5: 1$, and $(\mathrm{c})$ $\mathrm{Si} / \mathrm{C}$ mass ratio $=6: 1$.

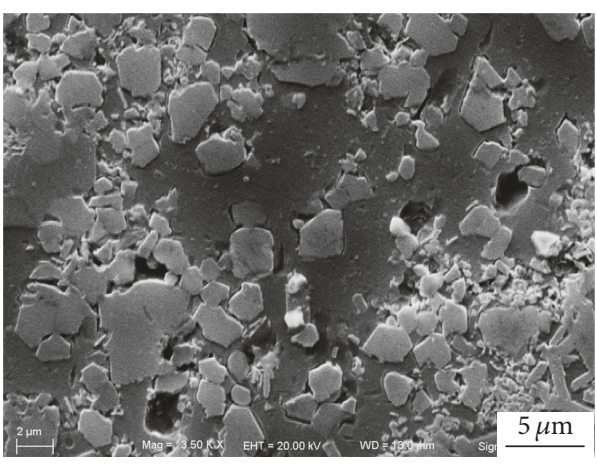

(a)

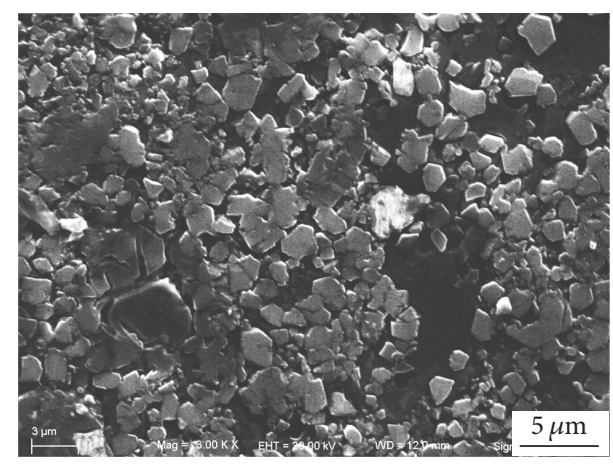

(b)

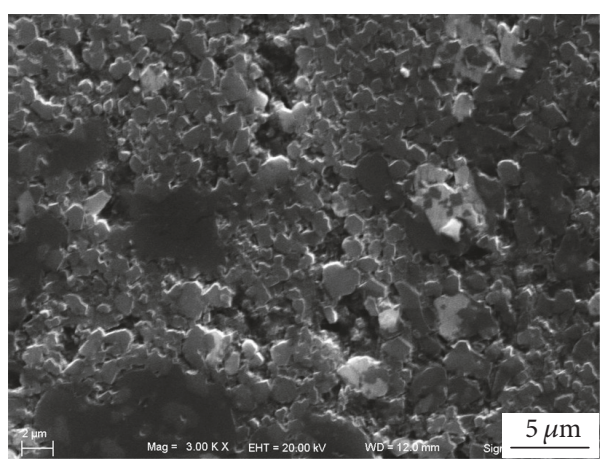

(c)

Figure 6: SEM images of the etched surfaces of the $\mathrm{SiC} / \mathrm{Al}$ composites with different $\mathrm{Si} / \mathrm{C}$ mass ratios: (a) $\mathrm{Si} / \mathrm{C}$ mass ratio $=4: 1$, (b) $\mathrm{Si} / \mathrm{C}$ mass ratio $=5: 1$, and $(\mathrm{c}) \mathrm{Si} / \mathrm{C}$ mass ratio $=6: 1$. 


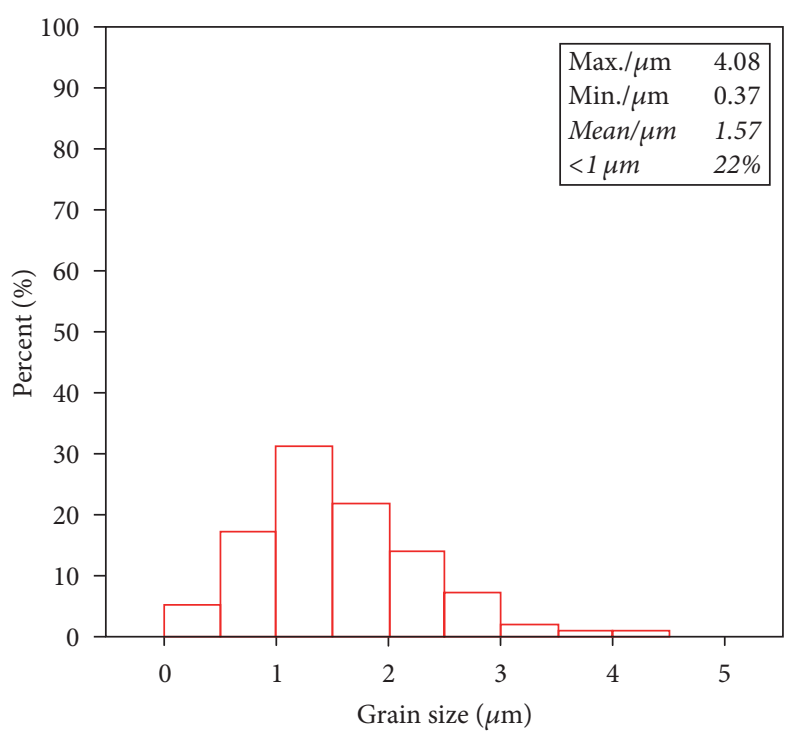

(a)

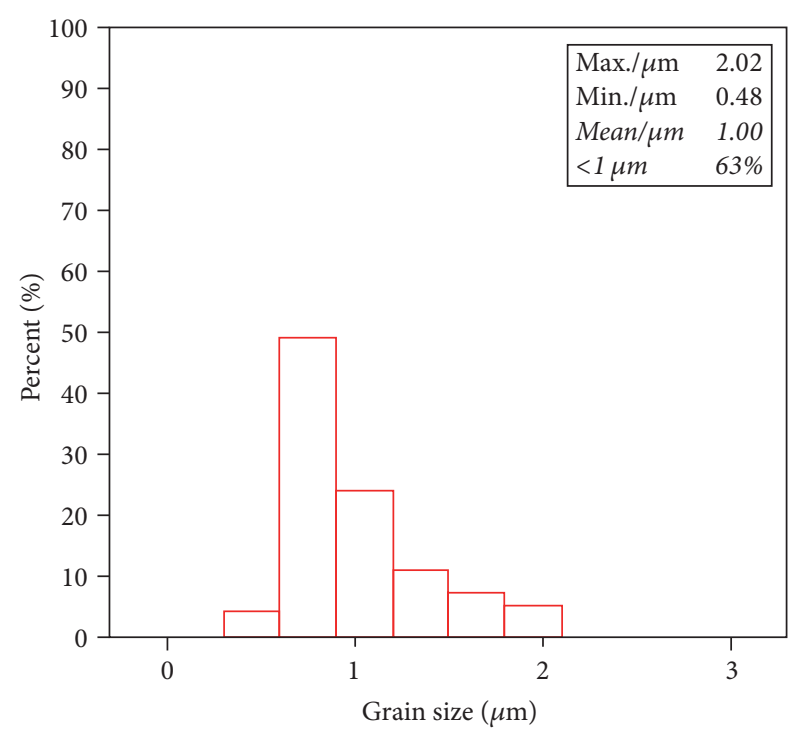

(b)

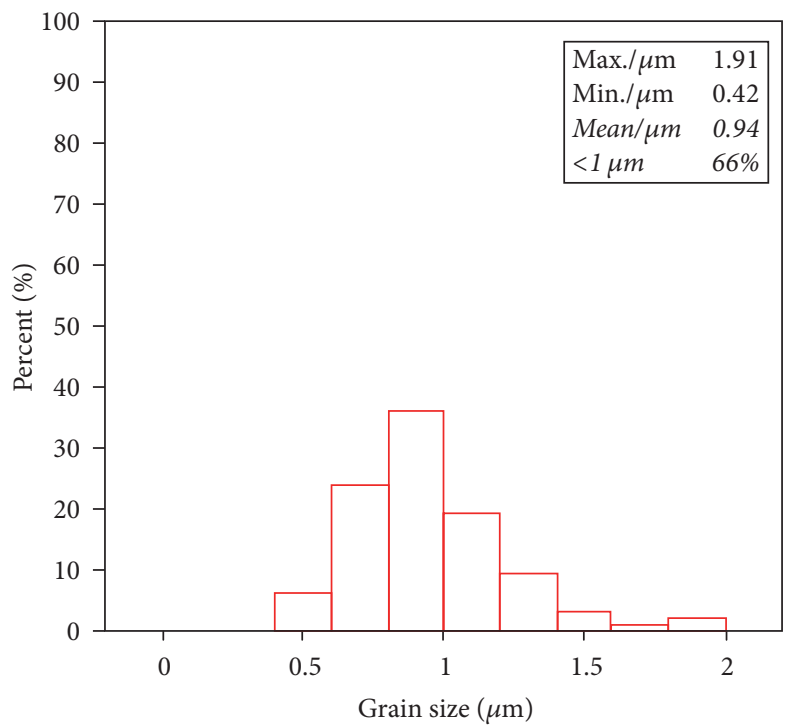

(c)

Figure 7: Size distribution of the $\mathrm{SiC}$ particles in the $\mathrm{SiC} / \mathrm{Al}$ composites with different $\mathrm{Si} / \mathrm{C}$ mass ratios: (a) $\mathrm{Si} / \mathrm{C}$ mass ratio $=4: 1$, (b) $\mathrm{Si} / \mathrm{C}$ mass ratio $=5: 1$, and $(\mathrm{c})$ Si $/ C$ mass ratio $=6: 1$.

In general, the $\mathrm{Al}_{4} \mathrm{C}_{3}$ phase plays a detrimental role in the mechanical properties of the composites [37]. Therefore, it is important to strictly control the residue of $\mathrm{Al}_{4} \mathrm{C}_{3}$ phase in the aluminum matrix composite. According to above results, the holding time should be chosen as $15 \mathrm{~min}$ for the fabrication of in situ $\mathrm{SiC} / \mathrm{Al}$ composites.

\section{Conclusions}

In this study, the in situ $\mathrm{SiC} / \mathrm{Al}$ composites are successfully fabricated by the method of combustion synthesis and hot press consolidation. With the increase of the $\mathrm{Si} / \mathrm{C}$ mass ratio, the size distribution of $\mathrm{SiC}$ particles becomes more uniform.
When the Si/C mass ratio increases from $4: 1$ to $5: 1$, the maximum size of $\mathrm{SiC}$ particles was reduced from $4.1 \mu \mathrm{m}$ to $2.0 \mu \mathrm{m}$. Meanwhile, the percentage of the submicroparticles was increased from $22 \%$ to $63 \%$ and the hardness value was increased by $13 \%$. In addition, without holding and with the holding time of $30 \mathrm{~min}$ in the fabrication process of the in situ $\mathrm{SiC} / \mathrm{Al}$ composites, the transition phase $\mathrm{Al}_{4} \mathrm{C}_{3}$ was residue. Furthermore if there is no holding time the $\mathrm{SiC}$ particles were few in composites; as a result the average hardness value was decreased by $21 \%$. When the holding time was set to be fifteen minutes, the $\mathrm{Al}_{4} \mathrm{C}_{3}$ phase totally reacts with $\mathrm{Si}$ atoms to form $\mathrm{SiC}$ particles, and the average hardness value was $73.8 \mathrm{HB}$. 


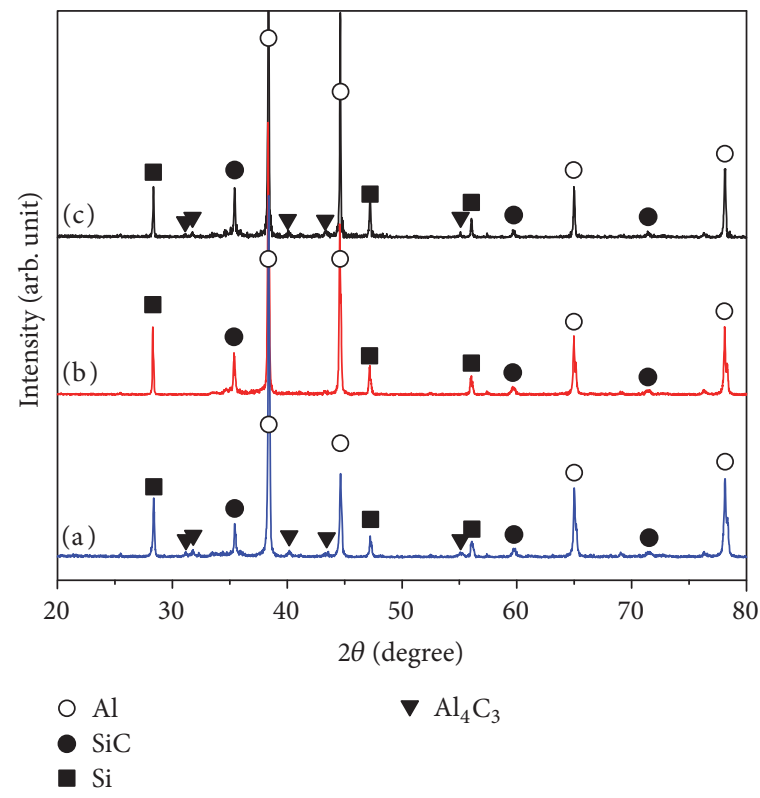

FIGURE 8: XRD patterns of the $\mathrm{SiC} / \mathrm{Al}$ composites with different holding times: (a) $0 \mathrm{~min}$, (b) $15 \mathrm{~min}$, and (c) $30 \mathrm{~min}$.

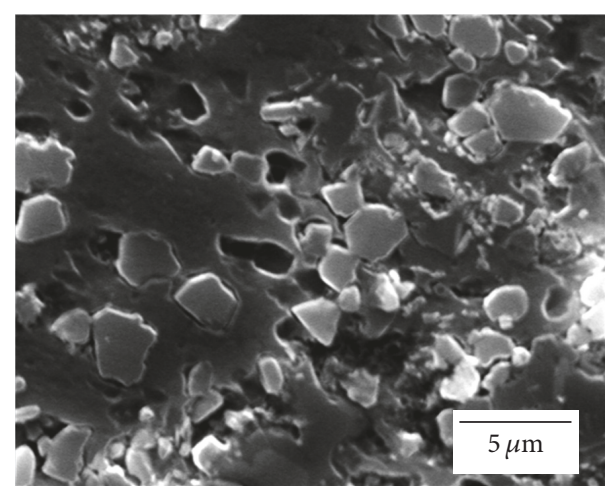

(a)

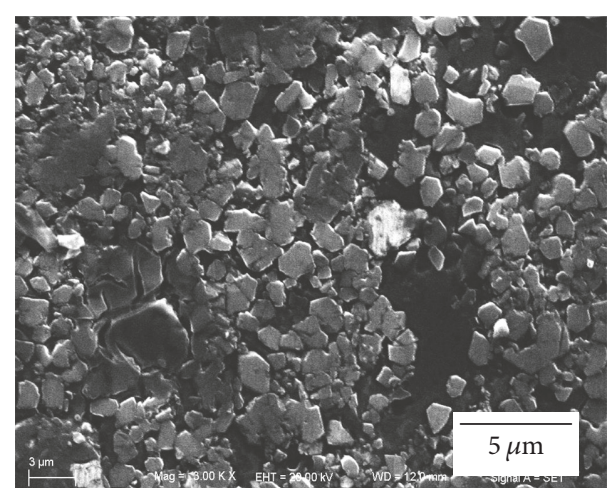

(b)

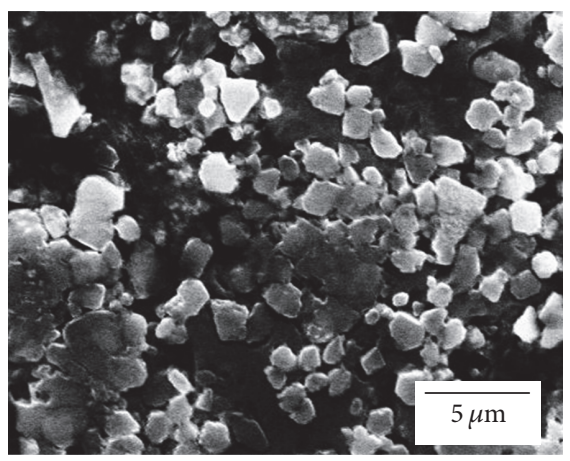

(c)

FIGURE 9: SEM images of the etched surfaces of the $\mathrm{SiC} / \mathrm{Al}$ composites with different holding times: (a) $0 \mathrm{~min}$, (b) $15 \mathrm{~min}$, and (c) $30 \mathrm{~min}$. 


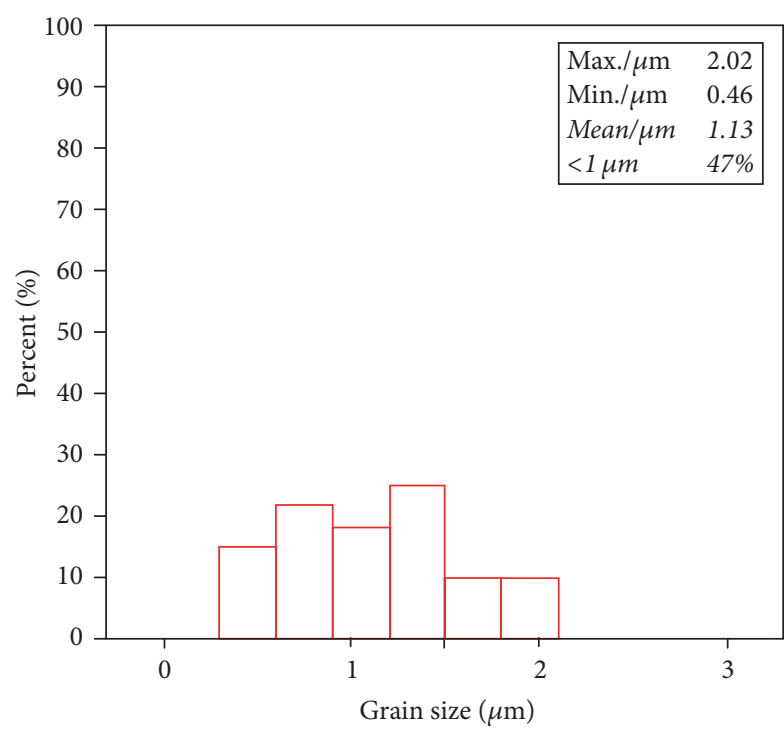

(a)

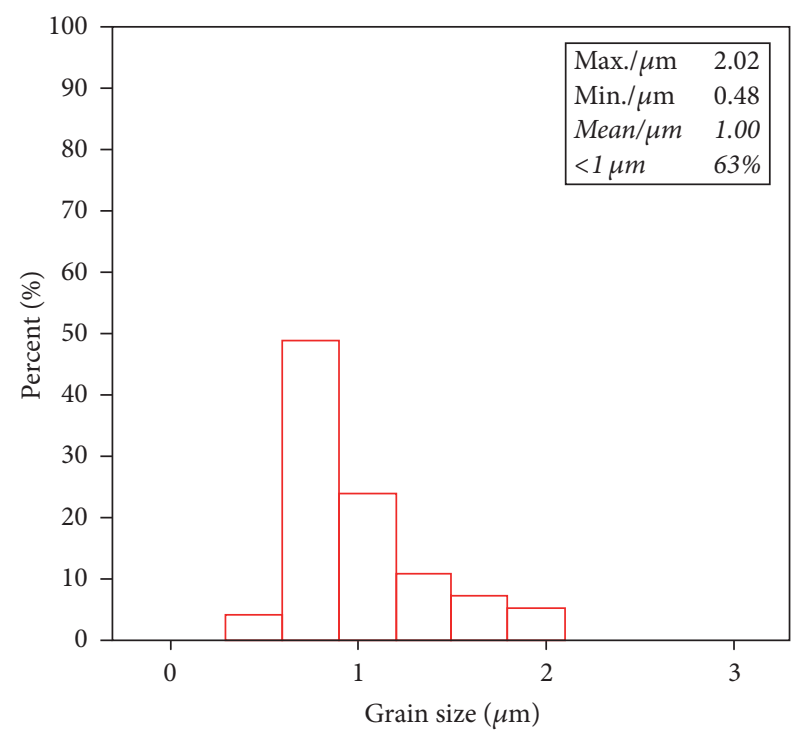

(b)

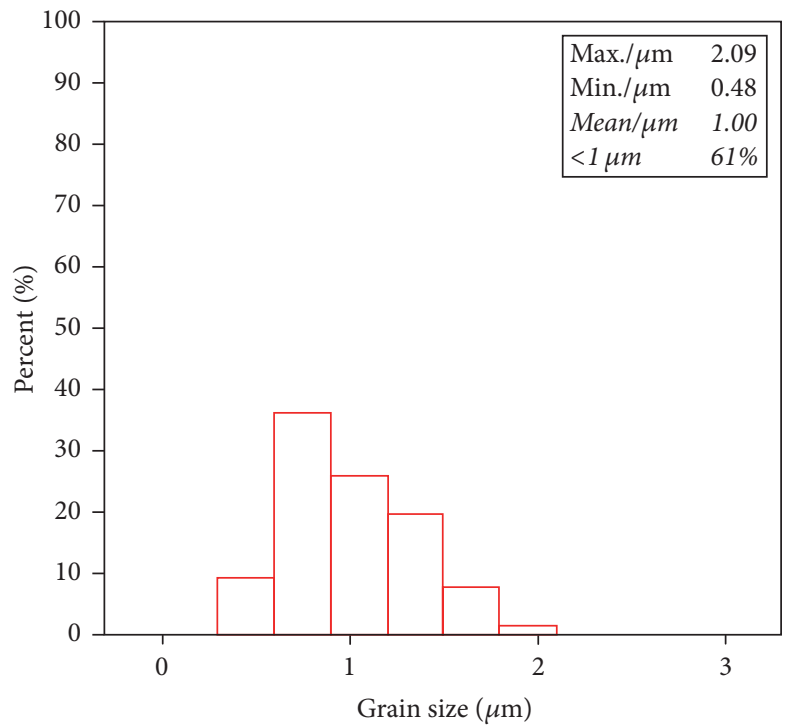

(c)

FIGURE 10: Size distribution of the $\mathrm{SiC}$ particles in the SiC/Al composites with different holding times: (a) 0 min, (b) $15 \mathrm{~min}$, and (c) $30 \mathrm{~min}$.

\section{Conflicts of Interest}

The authors declare that they have no conflicts of interest.

\section{Acknowledgments}

This work was financially supported by the National Natural Science Foundation of China (nos. 51501176 and 51701086).

\section{References}

[1] N. Gangil, A. N. Siddiquee, and S. Maheshwari, "Aluminium based in-situ composite fabrication through friction stir processing: A review," Journal of Alloys \& Compounds, vol. 715, pp. 91-104, 2017.
[2] L. Zhang, H. Xu, Z. Wang, Q. Li, and J. Wu, "Mechanical properties and corrosion behavior of $\mathrm{Al} / \mathrm{SiC}$ composites," Journal of Alloys \& Compounds, vol. 678, pp. 23-30, 2016.

[3] D. Yang, F. Qiu, W. Zhao, P. Shen, H. Wang, and Q. Jiang, "Effects of Ti-coating layer on the distribution of SiCP in the SiCP/2014Al composites," Materials and Corrosion, vol. 87, pp. 1100-1106, 2015.

[4] L.-J. Zhang, D.-L. Yang, F. Qiu, J.-G. Wang, and Q.-C. Jiang, "Effects of reinforcement surface modification on the microstructures and tensile properties of SiCp/Al2014 composites," Materials Science and Engineering: A Structural Materials: Properties, Microstructure and Processing, vol. 624, pp. 102-109, 2015.

[5] L. Wang, F. Qiu, Q. Zou et al., "Microstructures and tensile properties of nano-sized $\mathrm{SiC} \mathrm{p} / \mathrm{Al}-\mathrm{Cu}$ composites fabricated 
by semisolid stirring assisted with hot extrusion," Materials Characterization, vol. 131, pp. 195-200, 2017.

[6] X. Du, T. Gao, G. Liu, and X. Liu, "In situ synthesizing SiC particles and its strengthening effect on an $\mathrm{Al}-\mathrm{Si}-\mathrm{Cu}-\mathrm{Ni}-\mathrm{Mg}$ piston alloy," Journal of Alloys \& Compounds, vol. 695, pp. 1-8, 2017.

[7] M. Schöbel, W. Altendorfer, H. P. Degischer et al., "Internal stresses and voids in $\mathrm{SiC}$ particle reinforced aluminum composites for heat sink applications," Composites Science and Technology, vol. 71, no. 5, pp. 724-733, 2011.

[8] H. M. Zakaria, "Microstructural and corrosion behavior of $\mathrm{Al} / \mathrm{SiC}$ metal matrix composites," Ain Shams Engineering Journal, vol. 5, no. 3, pp. 831-838, 2014.

[9] D.-L. Yang, F. Qiu, Z.-K. Lei, Q.-L. Zhao, and Q.-C. Jiang, “The interfacial structure and mechanical properties of Ti5Si3-coated $\mathrm{SiCP} / \mathrm{Al} 2014$ composites fabricated by powder metallurgy with hot pressing," Materials Science and Engineering: A Structural Materials: Properties, Microstructure and Processing, vol. 661, pp. 217-221, 2016.

[10] L.-J. Zhang, F. Qiu, J.-G. Wang, and Q.-C. Jiang, "High strength and good ductility at elevated temperature of nano-SiCp/Al2014 composites fabricated by semi-solid stir casting combined with hot extrusion," Materials Science and Engineering: A Structural Materials: Properties, Microstructure and Processing, vol. 626, pp. 338-341, 2015.

[11] I. Balasubramanian and R. Maheswaran, "Effect of inclusion of $\mathrm{SiC}$ particulates on the mechanical resistance behaviour of stircast AA6063/SiC composites," Materials and Corrosion, vol. 65, pp. 511-520, 2015.

[12] L.-J. Zhang, F. Qiu, J.-G. Wang, H.-Y. Wang, and Q.-C. Jiang, "Microstructures and mechanical properties of the Al2014 composites reinforced with bimodal sized SiC particles," Materials Science and Engineering: A Structural Materials: Properties, Microstructure and Processing, vol. 637, pp. 70-74, 2015.

[13] Z. Chen, Z. Tan, G. Ji et al., "Effect of Interface Evolution on Thermal Conductivity of Vacuum Hot Pressed SiC/Al Composites," Advanced Engineering Materials, vol. 17, no. 7, pp. 1076-1084, 2015.

[14] H. Lee, S. S. Sohn, C. Jeon, I. Jo, S.-K. Lee, and S. Lee, "Dynamic compressive deformation behavior of SiCparticulate-reinforced A356 Al alloy matrix composites fabricated by liquid pressing process," Materials Science and Engineering: A Structural Materials: Properties, Microstructure and Processing, vol. 680, pp. 368-377, 2017.

[15] Z. Wei, P. Ma, H. Wang et al., "The thermal expansion behaviour of SiCp/Al-20Si composites solidified under high pressures," Materials and Corrosion, vol. 65, pp. 387-394, 2015.

[16] B.-K. Hwu, S.-J. Lin, and M.-T. Jahn, "Effects of process parameters on the properties of squeeze-cast SiCp-6061 Al metal-matrix composite," Materials Science and Engineering: A Structural Materials: Properties, Microstructure and Processing, vol. 207, no. 1, pp. 135-141, 1996.

[17] L. M. Tham, M. Gupta, and L. Cheng, "Effect of limited matrixreinforcement interfacial reaction on enhancing the mechanical properties of aluminium-silicon carbide composites," Acta Materialia, vol. 49, no. 16, pp. 3243-3253, 2001.

[18] I. A. Ibrahim, F. A. Mohamed, and E. J. Lavernia, "Particulate reinforced metal matrix composites-a review," Journal of Materials Science, vol. 26, no. 5, pp. 1137-1156, 1991.

[19] L. Wang, F. Qiu, L. Ouyang et al., "A novel approach of using ground CNTs as the carbon source to fabricate uniformly distributed nano-sized TiCx/2009Al composites," Materials , vol. 8, no. 12, pp. 8839-8849, 2015.

[20] Z. Wang, K. G. Prashanth, S. Scudino et al., "Tensile properties of $\mathrm{Al}$ matrix composites reinforced with in situ devitrified $\mathrm{Al}_{84} \mathrm{Gd}_{6} \mathrm{Ni}_{7} \mathrm{Co}_{3}$ glassy particles," Journal of Alloys and Compounds, vol. 586, no. 1, pp. S419-S422, 2014.

[21] D. Markó, K. G. Prashanth, S. Scudino et al., "Al-based metal matrix composites reinforced with Fe49.9Co35.1Nb7.7B4.5Si2.8 glassy powder: Mechanical behavior under tensile loading," Journal of Alloys and Compounds, vol. 615, no. 1, pp. S382-S385, 2015.

[22] Z. Wang, J. Tan, B. A. Sun et al., "Fabrication and mechanical properties of Al-based metal matrix composites reinforced with $\mathrm{Mg}_{65} \mathrm{Cu}_{20} \mathrm{Zn}_{5} \mathrm{Y}_{10}$ metallic glass particles," Materials Science and Engineering: A Structural Materials: Properties, Microstructure and Processing, vol. 600, pp. 53-58, 2014.

[23] S. C. Tjong and Z. Y. Ma, "Microstructural and mechanical characteristics of in situ metal matrix composites," Materials Science and Engineering: R: Reports, vol. 29, no. 3, pp. 49-113, 2000.

[24] L. Wang, F. Qiu, J. Liu et al., "Microstructure and tensile properties of in situ synthesized nano-sized $\mathrm{TiCx} / 2009 \mathrm{Al}$ composites," Materials \& Design, vol. 79, pp. 68-72, 2015.

[25] B. AlMangour, D. Grzesiak, and J.-M. Yang, "In-situ formation of novel TiC-particle-reinforced 316L stainless steel bulk-form composites by selective laser melting," Journal of Alloys and Compounds, vol. 706, pp. 409-418, 2017.

[26] B. S. S. Daniel, V. S. R. Murthy, and G. S. Murty, "Metal-ceramic composites via in-situ methods," Journal of Materials Processing Technology, vol. 68, no. 2, pp. 132-155, 1997.

[27] J. Nie, D. Li, E. Wang, and X. Liu, "In-situ synthesis of SiC particles by the structural evolution of TiCx in AlSi melt," Journal of Alloys \& Compounds, vol. 613, no. 613, pp. 407-412, 2014.

[28] X. Du, T. Gao, D. K. Li, Y. Wu, and X. Liu, "A novel approach to synthesize SiC particles by in situ reaction in $\mathrm{Al}-\mathrm{Si}-\mathrm{C}$ alloys," Journal of Alloys \& Compounds, vol. 588, no. 10, pp. 374-377, 2014.

[29] T. Gao, D. Wang, X. Du, D. Li, and X. Liu, "Phase transformation mechanism of Al4C3by the diffusion of Si and a novel method for in situ synthesis of $\mathrm{SiC}$ particles in $\mathrm{Al}$ melt," Journal of Alloys and Compounds, vol. 685, pp. 91-96, 2016.

[30] L. Wang, F. Qiu, Q. Zhao, H. Wang, and Q. Jiang, "Simultaneously increasing the elevated-temperature tensile strength and plasticity of in situ nano-sized TiCx/Al-Cu-Mg composites," Materials Characterization, vol. 125, pp. 7-12, 2017.

[31] L. Wang, F. Qiu, Q. Zhao, M. Zha, and Q. Jiang, "Superior high creep resistance of in situ nano-sized $\mathrm{TiCx} / \mathrm{Al}-\mathrm{Cu}-\mathrm{Mg}$ composite," Scientific Reports, vol. 7, no. 1, article 4540, 2017.

[32] Q. Zhao, Y. Liang, Z. Zhang, X. Li, and L. Ren, "Study on the impact resistance of bionic layered composite of $\mathrm{TiC}-\mathrm{TiB} 2 / \mathrm{Al}$ from Al-Ti-B4C system," Materials, vol. 9, no. 8, article 708, 2016.

[33] P. Ma, Y. Jia, K. G. Prashanth et al., "Effect of Si content on the microstructure and properties of Al-Si alloys fabricated using hot extrusion," Journal of Materials Research, vol. 32, no. 11, pp. 2210-2217, 2017.

[34] Y. Birol, "Microstructural evolution during annealing of a rapidly solidified Al-12Si alloy," Journal of Alloys and Compounds, vol. 439, no. 1-2, pp. 81-86, 2007. 
[35] K. G. Prashanth, S. Scudino, H. J. Klauss et al., "Microstructure and mechanical properties of Al-12Si produced by selective laser melting: Effect of heat treatment," Materials Science and Engineering: A Structural Materials: Properties, Microstructure and Processing, vol. 590, pp. 153-160, 2014.

[36] K. G. Prashanth, S. Scudino, A. K. Chaubey et al., "Processing of Al-12Si-TNM composites by selective laser melting and evaluation of compressive and wear properties," Journal of Materials Research, vol. 31, no. 1, pp. 55-65, 2016.

[37] H. Li, J. Kang, C. He, N. Zhao, C. Liang, and B. Li, "Mechanical properties and interfacial analysis of aluminum matrix composites reinforced by carbon nanotubes with diverse structures," Materials Science \&amp; Engineering A, vol. 577, no. 9, pp. 120124, 2013. 

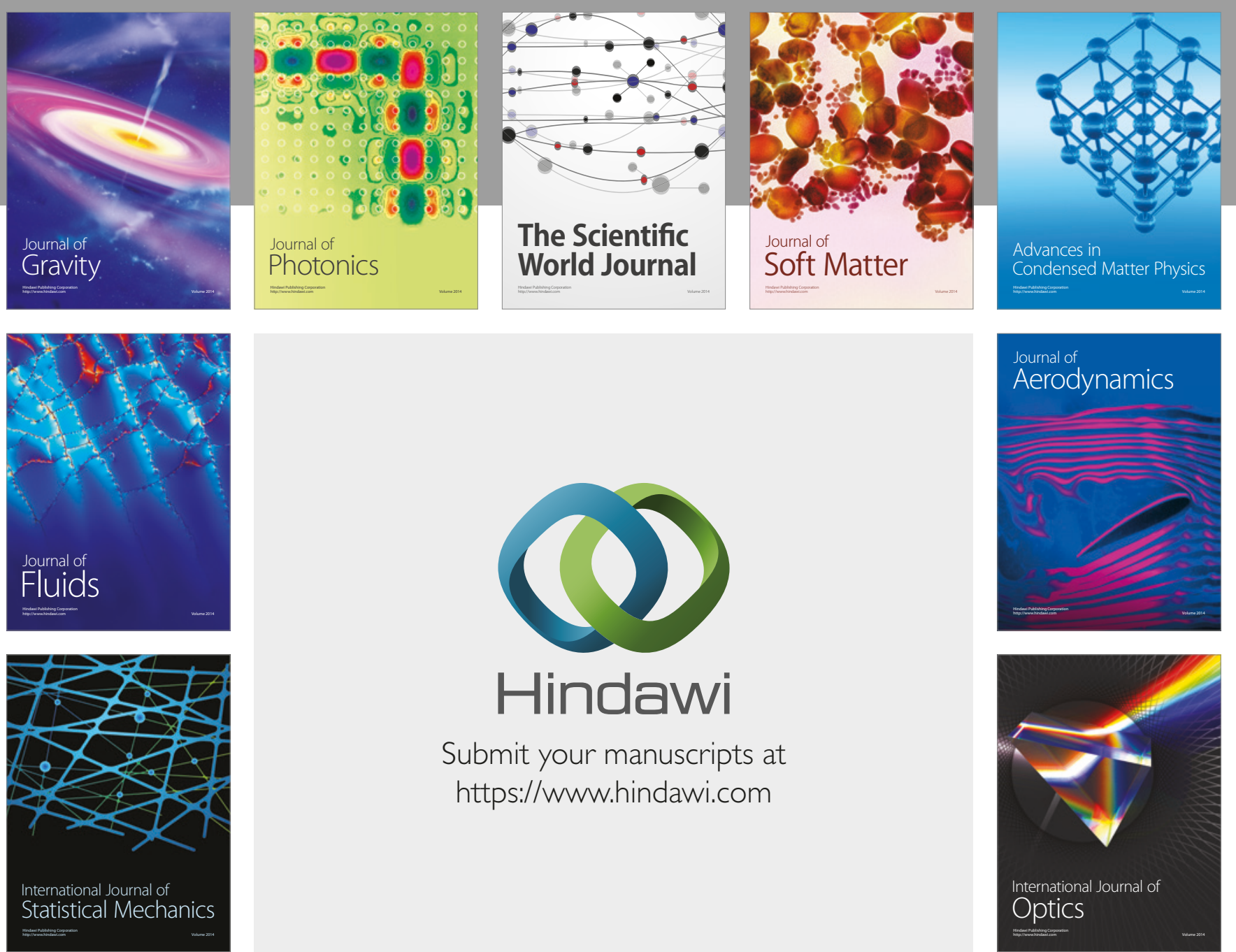

Submit your manuscripts at

https://www.hindawi.com
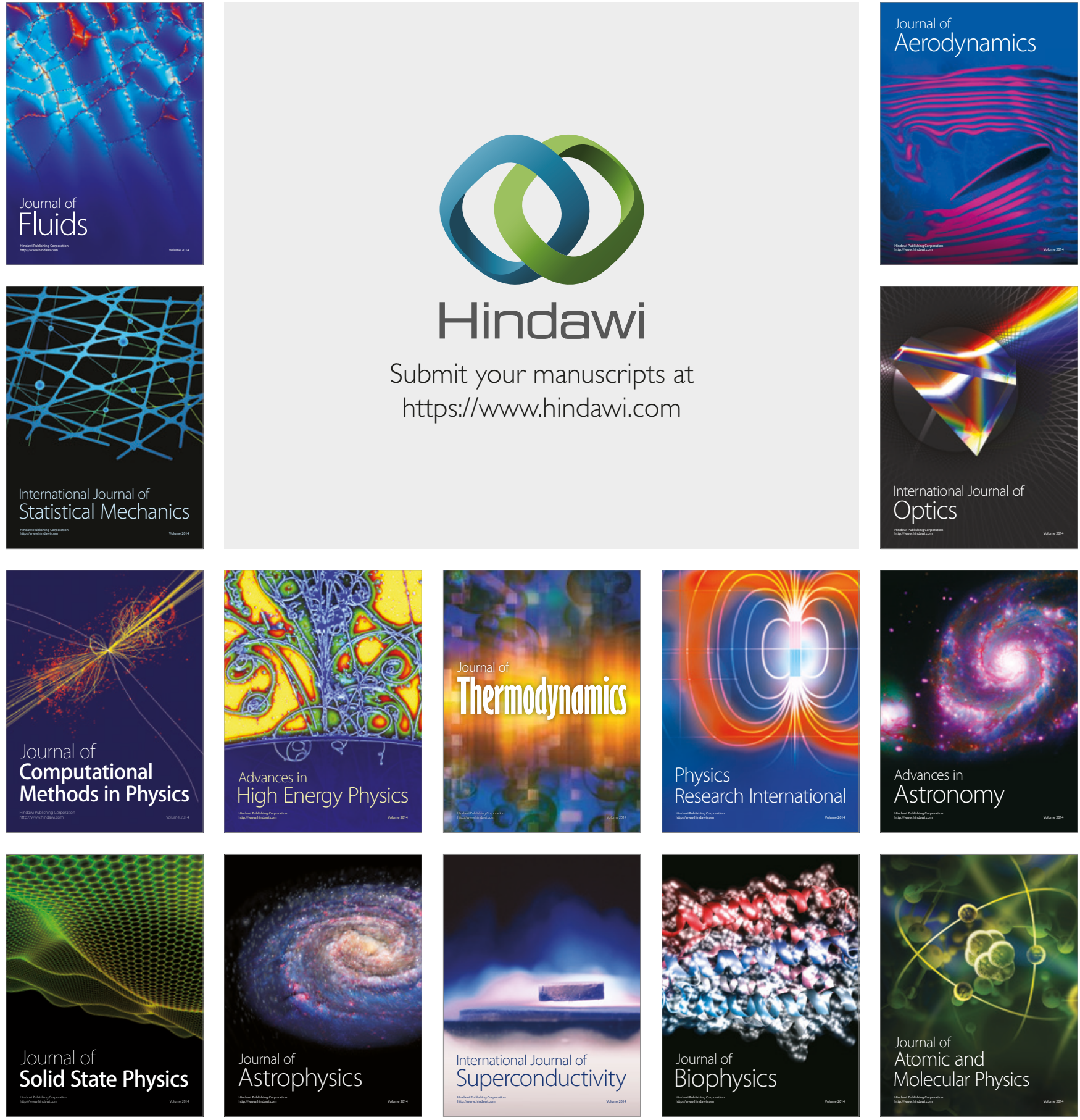